\title{
Organizational Culture and Open Innovation Performance in Small and Medium-sized Enterprises (SMEs) in Poland
}

\begin{abstract}
This study investigates the links between organizational culture, the use of open innovation sources and the performance of SMEs. The main hypothesis of the study is that a special type of organizational culture (termed innovative culture), which fosters creativity, learning and inter-employee cooperation - will correspond with a greater scope of open innovation sources and higher levels of innovative, operational and financial performance. The study was based on a representative CATI survey of 473 SMEs operating in manufacturing and services industries in Poland. Our statistical analysis relied on building and testing structural equation model with the AMOS software. The findings confirmed a positive association between innovative culture and the scope of open sources of innovation. However, innovative culture had no direct effect on the percentage of sales from new and modified products, which is often used as a metric of innovativeness, but did show a positive influence on an index of operational performance and ROI. Such statistical patterns suggest that fostering innovative culture is beneficial to a company, though probably not through an increased number of product innovations, but rather via process, administrative and marketing innovations, as well as other gains in efficiency attained due to more streamlined employee cooperation and knowledge exchange. The study adds to the existing body of knowledge in management science by providing a better understanding of mechanisms underlying innovative culture's impacts on open innovation
\end{abstract}


practices and metrics of operational and financial performance in the context of small and medium enterprises.

Keywords: organizational culture, innovative culture, open innovation, innovation performance, SMEs

JEL: M14, M54, O32

\section{Introduction}

Innovation is a major challenge facing organizations in the contemporary competitive environment. It is inevitable not only during times of prosperity, but also during a downturn as there is "significant business value to be gained by using innovation as a powerful tool for bottom line optimization" [Arthur D. Little, 2008]. Numerous studies have indicated a positive impact of innovations on firm performance [Guan, Ma, 2003; Hult, Hurley, Knight, 2004; Verhees, Meulenberg, 2004; Hilman, Kaliappen, 2015].

According to Chesbrough [2003a], global distribution of manufacturing and business process knowledge and insights, development and growth of low cost manufacturers and shrinking product life cycles create an environment in which sustained innovation is a major condition of sustainable competitiveness and profitable growth. Lack of innovation turns products into commodities and suppliers and their brands tend to lose their uniqueness. There are two models of sustaining innovative activities in order to escape the commodity trap: either to concentrate on the search for new innovative opportunities internally, devoting large resources to developing internal $\mathrm{R} \& \mathrm{D}$, or to rely on external knowledge sources. New technologies have increased the accessibility of external knowledge and complementary assets, and significantly expanded the potential for capturing knowledge from outside of the company and the use of it to develop innovative products [Chesbrough, 2003b]. Knowledge multisourcing and sharing have turned into an attractive innovation managing alternative, especially for large corporations [Chesbrough, Brunswicker, 2013; Chesbrough, Vanhaverbeke, West, 2006].

The particular model characterized by sourcing innovations from external partners (outside-in) and sharing one's own knowledge with others (inside-out) was named "open innovation" (OI). Chesbrough defined OI as "the use of purposive inflows and outflows of knowledge to accelerate internal innovation, and expand markets for external use of innovation" [Chesbrough, Vanhaverbeke, West, 2006, p. 1]. "The open innovation paradigm can be understood as the antithesis of the traditional vertical integration model where internal research and development activities lead to internally developed products that are then distributed by the firm" [Chesbrough, 2006, p. 15]. 
Open innovation management is focused on exploring and exploiting a variety of innovation opportunities. It is deeply rooted in the co-creation concept, which is supported by von Hippel [2005], Vargo and Lusch [2004], Prahalad and Ramaswamy [2004]. Interestingly, referring to Chesbrough's study [2003], Theyel [2012] described open innovation as an example of an organizational innovation [2012], arguing that the novelty of this model lies in integrating internal capabilities with external ones. The ability to integrate valuable resources and capabilities is the basic condition of a sustainable competitive advantage according to the resource-based view [Penrose, 1959; Wernerfelt, 1984]. Resource integration as a function of the firm is also pointed out in the SDL concept [Vargo, Lush, 2004].

In the systematically growing literature exploring applications of the OI model, one can find empirical studies investigating the influence of knowledge multisourcing on firm innovation performance [Katila, Ahuja, 2002; Bullinger et al. 2004; Laursen, Salter, 2006; Lettl et al., 2006; Piller, Walcher, 2006; Zeng et al, 2010; Inauen, Schenker-Wicki, 2011; Mazur, Zaborek, 2015]. They confirm the beneficial effects of acquiring external sources of knowledge on firms' innovative performance as some authors find that application of various sourcing methods may result in different innovation effects. [Katila, Ahuja, 2002; Laursen, Salter, 2006; Kang, Kang, 2009].

In a study explaining how knowledge searching behavior influences a firm's performance in introducing new products Katila and Ahuja [2002] identified two knowledge search dimensions: its depth, understood as the frequency of a firm reusing its existing knowledge, and its scope, understood as determining how widely the firm explores new knowledge. Taking into consideration the costs of oversearching in both dimensions, the authors hypothesized about the curvilinear relation of search depth and search scope with the number of new products introduced by an organization. The exploration of industrial robotics companies' searching behavior in Europe, Japan, and North America was based on secondary data. The results confirmed that new product market introduction is determined by moderating effects of both search dimensions. Contrary to expectations, a linear effect of a search scope on new product innovation was observed. Laursen and Slater [2006] studied the impact of the same two attributes of a firm's openness in external search strategies, i.e. the concepts of breadth (understood as scope) and depth, on an organization's innovativeness. The results of their empirical study drawn from survey data from U.K. manufacturing firms showed that searching widely and deeply tends to improve firms' innovation performance. However, this positive effect is observed only up to a certain point, afterwards adding a new source channel is unproductive [2006, pp. 131-132].

Other subjects studied in the literature include: major innovation sources [Enkel, Gassmann, 2008, 2010], OI motives [Van de Vrande et al., 2009] and inside-out open innovation as a driver of business performance [Lichtenthaler, 2009].

Among major OI themes warranting further research, Gassman, Enkel, Chesbrough [2010, pp. 213-214] pointed to the cultural perspective, highlighting the importance of organizational culture (understood as values and approaches, management strategies and 
instruments, information systems and other artifacts) in implementing the OI model. In the same paper the authors found OI activities in SMEs to be under-researched in available publications. This observation was shared by Huinzingh [2011] and Huang [2013]. According to Gassman et al. [2010] studies on SMEs would help managers determine how to deal with open innovation efficiently. The need for including organizational culture into studies on SMEs' innovation is also voiced by Van de Vrande et al. [2009]. They suggest that corporate organization and culture (affecting inter-organization relationships) are the major barriers restricting implementation of the OI model in Dutch manufacturing and services SMEs.

In the above-outlined context, the objective of the study is to diminish the knowledge gap concerning organizational culture's impact on SMEs' OI practices and their outcomes. The research is based on a survey of Polish SMEs representing the manufacturing and services sectors.

The paper is structured as follows: first, our literature review section investigates different ways of understanding and operationalizing the construct of organizational culture. Based on the existing literature we consider an innovative culture as a special case of organizational culture and its links with the innovative performance of businesses. The literature section concludes with a discussion of the dimensionality of innovative culture in previous research and in this article. Next, a conceptual model and hypotheses are presented, and research method outlined. Finally, findings and implications are discussed.

\section{Literature Background}

\section{Defining Organizational Culture}

In management science, organizational culture is widely studied and considered a crucial determinant of the organization's performance. However, according to Watkins "while there is universal agreement that it exists and plays a crucial role in shaping behavior in organizations, there is little consensus on what organizational culture actually is" [2013]. Accordingly, a multitude of definitions are cited in the literature on the topic. Among them, the simplest and most frequently used defines organizational culture as "the way we do things around here to succeed" [Lundy, Cowling, 1996]. According to Schein, culture is "an abstraction but its behavioral and attitudinal consequences are very concrete" [2004, p. 8]. It is a dynamic phenomenon "created by our interactions with others and shaped by leadership behavior, and a set of structures, routines, rules, and norms that guide and constrain behavior" [2004, p. 1].This definition also applies to organizational culture, or any group culture. Schein points out that "dynamic processes of culture creation and management are the essence of leadership" [2004, p. 1]. He opposes evaluating cultures in an absolute sense, as there are no "good" or "bad" cultures. What really matters is the 
relationship of a culture to the surrounding environment; in particular, societal culture. Indeed, according to Conrad and Poole, "organizations are embedded in societies and cannot be understood outside of a society's beliefs, values, structures, practices, tension and ways of managing those tensions" [2012, p. 5]. Schein presents a list of categories by various authors that identify groups of cultures by shared or common elements, such as observed behavioral regularities, group norms, espoused values, formal philosophy, rules of the game, climate, and many others [2004, pp. 12-13]. He suggests that although these categories relate to culture and can be viewed as culture manifestations, they themselves are not "the culture". According to Schein, culture is usually an unconscious group characteristic, stable and hard to change. It permeates all aspects of group functioning and ties together all elements into a coherent whole. Schein distinguishes between three levels of culture. The upper level is artifacts, i.e. a visible physical environment, products, style, myths and stories, observable rituals, etc. The second level consists of conscious espoused beliefs and values, such as strategies, goals, and philosophies. They can be discussed and modified. The deepest culture level is basic underlying assumptions. They are unconscious, taken for granted beliefs, perceptions, thoughts and feelings, which form a source of both values and actions [2004, pp. 25-37]. This level is the core of a culture.

Schein defines organizational culture as "a pattern of shared basic assumptions that was learned by a group as it solved its problems of external adaptation and internal integration that has worked well enough to be considered valid and, therefore, to be taught to new members as the correct way to perceive, think, and feel in relation to those problems" [2004, p. 17].

Another comprehensive study on approaches to organizational culture was presented by Deshpandé and Webster [1989]. Referring to Smircich's previous work [1983] they distinguished the following major understandings of organizational culture found in the literature: (1) exogenous, independent variable; (2) endogenous, independent variable; (3) culture as a metaphor for organizational knowledge systems; (4) culture as a metaphor for shared symbols and meanings; and (5) culture as a metaphor for an unconscious mind grounded in various organizational science paradigms. The authors examined these paradigms in terms of their potential contribution to the study of marketing management, and observed that a rapidly developing literature on organizational culture brought about many definitional, conceptual, and methodological issues that had to be solved by researchers. Pointing to a lack of consensus about the definition and measurement of organizational culture they proposed the following definition of their own: "the pattern of shared values and beliefs that help members of an organization understand why things happen and thus teach the behavioral norms in the organization" [p. 4].

Hurley and Hult [1998, p. 47] support the conceptualization of culture as a "system of beliefs in which actors internalize some meaningful order with respect to the organization" [Barney 1986; Schwartz, Davis, 1981]. Many researchers attempt to study organizational culture as "the values, beliefs and hidden assumptions that organizational members have 
in common" [Cameron, Quinn, 1999; Naranjo Valencia, Sanz Valle, Jiménez Jiménez, 2010], which is an approach that rests on the notion that hidden assumptions can be discovered through observed values and beliefs (espoused beliefs and values according to Schein [1989, p.4]). As such, in many empirical papers it seems that what is really being studied are artifacts, beliefs and values, and not the core of organizational culture. The problem is that many artifacts, beliefs and values can be interpreted in various ways, which can mislead the observer as to the basic assumptions that are the true culture core. On the other hand, many research methods (e.g. quantitative surveys) preclude first-hand, extensive involvement with organizations and their employees, which seems necessary to establish basic assumptions. Therefore, the next best thing may be to rely on proxy variables that are easier to observe, such as values, beliefs, and even recurring behavioral patterns, just as we do in this paper.

Organizational culture differs across organizations and even among departments of the same organization. Organizational cultures may be more or less ethical [Riivari et al., 2012], and more or less innovative. In our opinion, there is only one organizational culture of a certain group of people at a single point in time. So the suggestion that "organizational culture plays a key role in developing knowledge culture" [Oliver, Kandadi, 2006, p. 19] is misguided. Unless, that is, the authors consider the current culture as a better or worse starting point in the process of turning it into an innovative culture. The same reservations concern the efforts of exploring the relationships between organizational culture and innovation culture in the organization [Sharifirad, Ataei, 2012]. In other words, we do believe that organizational culture can be more or less conducive to innovating, but innovation culture does not exist separate from the general culture of a business entity. As such, innovative culture is achieved through the process of organizational culture modifications [Simpson et al., 2006] supporting new knowledge creation by adopting new ideas (products) and behavior [Herkema, 2003].

\section{Organizational Culture and Innovation}

Towards the end of the $20^{\text {th }}$ century the growing dependence of organizations' success on their innovative capacity made studying determinants of company innovativeness very relevant. A chronology of research on creativity and innovation in organizations is briefly presented by McLean [2005]. According to De Long: "Any knowledge management strategy designed to improve business performance must address three components: (1) the work processes or activities that create and leverage organizational knowledge; (2) the technology infrastructure to support knowledge capture, transfer, and use; and (3) behavioral norms and practices often labeled "organizational culture" that are essential to effective knowledge use" [De Long, 1997, p. 2].

The importance of organizational culture in such domains as innovation and knowledge management is underlined in many later publications [Ruppel, Harrington, 2002; Janz., Prasarnphanich, 2003; Alavi, Kayworth, Leidner, 2005: Chang, Lin, 2015]. Studies 
addressing determinants of organization's innovation pointed to organizational culture as the crucial factor in moderating the intensity of innovative activity and its outcomes [Higgins, McAllaster, 2002; Jassawalla, Sashittal, 2002; Martins, Terblanche, 2003; McLean, 2005 Jamrog et al., 2006; Koc, Ceylan, 2007; Laforet, 2015; Riivari et al., 2012; Naranjo-Valencia et al., 2011]. Within a set of works concerning relations between organizational culture and innovation two groups of publications can be identified. The articles in the first group outline culture's restrictive impact on innovation [De Long, Fahey, 2000; McDermott, O'Dell, 2001]. Other publications in this group discuss an organizational culture as an innovation strategy barrier. Hurley and Hult, after Burns and Stalker [1961], described the capacity to innovate as "the ability of the organization to adopt or implement new ideas, processes, or products successfully" [1998, p. 44]. This capacity is underpinned by the interaction of culture and strategy, which have to fit together to induce innovations. If organizational culture does not support strategy, strategy will fail. McCracken pointed out such scenarios by quipping that "culture eats strategy for breakfast" [2006]. Therefore, in the case of strong organization cultures, "it may be more appropriate to tailor one's strategy to one's culture, rather than the other way around" [Gorman, 2007]. This problem is also discussed by Flynn and Chatman [2000]. The second group of publications is focused on organizational culture qualities which support innovation. The articles included there describe knowledge-oriented cultures, sharing cultures or innovation cultures, etc. [Zakaria et al., 2004; Oliver, Kendadi, 2006].

Some studies concerning organizational culture's impact on innovation distinguish types of innovation (innovations new to the market vs. imitations) to connect them with the most appropriate (supportive) types of organizational culture (adhocracy culture vs. hierarchical culture) [Naranjo-Valencia, et al., 2011].

From the perspective of the current study, the most important are publications concerning knowledge management and innovation management focused on the impact of organizational culture on an organization's innovation performance. This literature consists of both conceptual works and empirical studies. Martins and Terblanche article [2003] is an example of the first category. Performing an in-depth literature review the authors developed a model explaining the influence of organizational culture on creativity and innovation. Hurley and Hult [1998] combined conceptual deliberations on implementing innovation in organizations following the market orientation perspective with an empirical study. Its results indicated that higher levels of innovativeness are associated with cultures that emphasize learning, development, and participative decision making. The theoretical framework in a paper by Zheng [2009] integrates research on cultural factors influencing knowledge management effectiveness. Empirical studies of the association between innovation and organizational culture used data from various countries. The work by Deshpande et al. [1993] investigated corporate culture's impact on innovativeness in Japanese firms. According to Darroch and McNaughton's findings [2001] based on a survey of New Zealand companies, the highest innovativeness and the 
best financial performance were achieved by the knowledge-management companies, combining a learning culture with close attention to market dynamics. The results of a survey of Spanish firms enabled Sanz-Valle et al. [2011] concluded that organizational culture can foster organizational learning and product innovation.Jiménez-Jiménez and Sanz-Valle confirmed that organizational culture is a major determinant of innovation strategy. In her empirical study of family SMEs, Laforet [2015] found that entrepreneurial culture (externally oriented, flexible, open, and long-term oriented) positively influences innovation performance in British firms.

In the context of culture-innovation relationships, useful insights are to be found in a survey of 852 small and medium-sized Polish firms by Mazur, Rószkiewicz and Strzyżewska [2008, 2011]. The authors measured knowledge orientation levels in three categories of knowledge practices: data and information generation and sharing between departments of a single company, as well as new knowledge creation, application and sharing with value chain partners. The scale items concerned various aspects of learning and market orientation. The findings showed that the top ranked companies in all three knowledge practice categories (which can be interpreted as companies characterized by a strong knowledge culture) performed the best. What is also interesting, those companies were managed by knowledge oriented leaders (leaders of high level knowledge orientation).

Some other authors perceive knowledge centered leadership and knowledge centered human resource practices as moderators of the relationship between knowledge exploration and exploitation practices, and innovation outcomes [Donate, Guadamillas, 2011].

The above reported results led us expect that our sample companies' innovative culture will support their innovation practices. Despite a fair number of papers on interactions between organizational culture and innovation, as mentioned earlier, attempts to combine the open innovation model and organization culture have been scarce [Katila, Ahuja, 2002; Laursen, Salter, 2006; Inauen, Schenker-Wicki, 2011; Rass et al., 2013;] and therefore worth undertaking.

As a final note in this section, there is strong reason to believe that innovative culture, for its openness to external ideas and readiness to share knowledge, supports application of the open innovation model. This phenomenon is hardly noticed by organizational culture researchers. Santos-Vijande et al. [2013] called such a culture "co-creation culture" in their work investigating the influence of customers and first line employees on service firms' innovation capacity and performance [p. 90]. The results demonstrated that co-creation makes the surveyed organizations more innovative than their competitors.

\section{Organizational Culture Dimensions and Measurement}

In the context of organizational culture dimensions, it is pertinent to reference a major academic debate of the $1990 \mathrm{~s}$ concerning the possibility of measuring cultures (also organizational cultures) [Denison, 1996; Hatch, 1993]. According to Schein [1992] measuring basic assumptions (the culture core) is impossible. However, there have been 
numerous attempts at developing comparative culture measurement systems, usually at the level of values and behavioral norms [Denison et al., 2006; Homburg, Pflesser, 2000]. One example is the model of organizational culture by Denison et al. [2006], an experienced organizational culture researcher [Denison, 1984; 1990; 1996; 2000, Denison, Mishra, 1995; 1996, Fey, Denison, 2003], which is based on four cultural traits of organizations: involvement, consistency, adaptability, and mission. Each of these four traits, or dimensions, is measured by three five-item indices. The complete set of 12 culture indices (which can be considered sub-dimensions) comprises: empowerment, team orientation, capability development, core values, agreement, coordination and integration, creating change, customer focus, organizational learning, strategic direction and intent, goals and objective, and mission (p. 34).

There are many organization culture typologies proposed in the literature. The typology by Cameron and Quinn [1999] seems to be the most popular among researchers. The authors distinguished four culture types: adhocracy, clan, hierarchy and market cultures. They were identified by applying pairs of criteria: flexibility and discretion vs. stability and control, and internal focus vs. external focus. These criteria can also be treated as organizational culture dimensions.

Building on Hofstede's et al. [1990] behavioral manifestations of culture, Chang and Lin [2015] studied organizational cultures to distinguish the following defining criteria: results vs. process oriented, tightly controlled vs. loosely controlled, job-oriented vs. employee-oriented, closed system vs. open system, and professional vs. parochial. There, each pair of opposing descriptors corresponds to a single cultural dimension, such as control level, openness etc.

\section{Dimensions and Indicators of Innovative Culture}

Implementing the innovative culture construct in our research model required determining its dimensions and indicators to effectively differentiate between innovation-oriented cultures and non-innovative ones. A literature review on organizational culture revealed that no one universal set of dimensions is used. Some authors add several features to the "standard" organizational culture dimensions. Others list a few specific dimensions reflecting innovativeness. Table 1 shows examples of items in questionnaires and their corresponding dimensions proposed in several empirical and conceptual studies on innovation cultures, knowledge cultures and learning cultures. An analysis of the content of these three terms in academic publications leads us to conclude that their manifestations are often similar. However, one can also find sources where the meaning of the three concepts is different, which depends largely on the definition of organizational culture adopted by particular authors. For instance, a narrow definition of organization culture can result in perceiving learning to be external to the organizational culture, such as in Sanz-Valle et al. [2011].

Table 1 gives a comprehensive summary of definitions, conceptualizations and examples of scale items used in earlier studies that guided our research. In the last column we offer 
our interpretation regarding the focus areas or major dimensions of innovative culture in each of the cited works. In bold type are highlighted those themes that recurred most often in the literature and eventually ended up in our conceptual model as sub-dimensions of the innovative culture construct.

From the literature analysis we concluded that to comprehensively represent an organizational culture's capacity to foster innovations, three dimensions need to be accounted for: (1) creativity and risk taking, (2) internal cooperation and (3) learning focus. As such, our construct of innovative culture was composed of the three aforementioned elements.

\section{TABLE 1. Measures and dimensions of innovation/knowledge/learning cultures in previous publications}

\begin{tabular}{|c|c|c|c|}
\hline Source & $\begin{array}{l}\text { Construct } \\
\text { studied }\end{array}$ & Scale items for dimensions/measures & $\begin{array}{c}\text { Focus areas (See } \\
\text { note at the foot of } \\
\text { the table) }\end{array}$ \\
\hline $\begin{array}{l}\text { Donate and } \\
\text { Guadamillas } \\
\text { [2011] }\end{array}$ & $\begin{array}{l}\text { Knowledge- } \\
\text {-centered culture }\end{array}$ & $\begin{array}{l}\text { There has been a common language to support } \\
\text { knowledge exchange and sharing between } \\
\text { employees and departments. } \\
\text { An effort is made to encourage employees } \\
\text { to experiment and implement new ideas in the } \\
\text { working day. } \\
\text { An effort is made to inform employees that } \\
\text { mistakes are a learning consequence and are } \\
\text { tolerated up to a certain limit. } \\
\text { Culture is based on confidence and openness. } \\
\text { The employees demonstrate responsible behavior } \\
\text { and a high learning disposition. } \\
\text { All organizational members perceive the same } \\
\text { purpose and feel bound to it. }\end{array}$ & $\begin{array}{l}\text { Learning } \\
\text { Creativity } \\
\text { Openness } \\
\text { Internal } \\
\text { cooperation }\end{array}$ \\
\hline $\begin{array}{l}\text { Santos-Vijande } \\
\text { and González- } \\
\text {-Mieres [2013] }\end{array}$ & $\begin{array}{l}\text { Innovativeness = } \\
=\text { innovative } \\
\text { culture }\end{array}$ & $\begin{array}{l}\text { Innovation proposals are welcomed in the } \\
\text { organization. Management actively seeks } \\
\text { innovative ideas. Innovation is not perceived as } \\
\text { too risky and is not resisted. } \\
\text { People are not penalized for new ideas that do } \\
\text { not work. Management promotes and supports } \\
\text { innovative ideas, experimentation and creative } \\
\text { processes. Innovation is supported to cope with } \\
\text { competition. }\end{array}$ & $\begin{array}{l}\text { Innovation } \\
\text { Creativity and } \\
\text { risk taking }\end{array}$ \\
\hline
\end{tabular}




\begin{tabular}{|c|c|c|c|}
\hline Source & $\begin{array}{l}\text { Construct } \\
\text { studied }\end{array}$ & Scale items for dimensions/measures & $\begin{array}{c}\text { Focus areas (See } \\
\text { note at the foot of } \\
\text { the table) }\end{array}$ \\
\hline $\begin{array}{l}\text { Martins and } \\
\text { Terblanche } \\
\text { [2003] }\end{array}$ & $\begin{array}{l}\text { Determinants of } \\
\text { organizational } \\
\text { culture that } \\
\text { influence } \\
\text { creativity and } \\
\text { innovation }\end{array}$ & $\begin{array}{l}\text { Structure } \\
\text {-Flexibility } \\
\text {-Freedom } \\
\text {-Autonomy } \\
\text {-Empowerment } \\
\text {-Decision making } \\
\text {-Cooperative teams and group interaction } \\
\text { Support mechanisms } \\
\text {-Reward and recognition } \\
\text {-Availability of resources } \\
\text {-Time } \\
\text {-Information technology } \\
\text {-Creative people } \\
\text { Behavior that encourages innovation } \\
\text {-Mistake handling } \\
\text {-Idea generating } \\
\text {-Continuous learning culture } \\
\text {-Risk taking } \\
\text {-Competitiveness } \\
\text {-Support for change } \\
\text {-Conflict handling } \\
\text { Communication } \\
\text {-Open communication }\end{array}$ & $\begin{array}{l}\text { Internal } \\
\text { cooperation } \\
\text { Creativity and risk } \\
\text { taking } \\
\text { Innovation } \\
\text { Openness } \\
\text { Learning }\end{array}$ \\
\hline Dobni [2008] & $\begin{array}{l}\text { Innovation } \\
\text { culture }\end{array}$ & $\begin{array}{l}\text { Innovation propensity } \\
\text { Organizational consistency } \\
\text { Organizational learning } \\
\text { Creativity and empowerment } \\
\text { Market orientation } \\
\text { Value orientation } \\
\text { Implementation context }\end{array}$ & $\begin{array}{l}\text { Creativity- } \\
\text { Innovation } \\
\text { Learning } \\
\text { Internal } \\
\text { consistency } \\
\text { Market } \\
\text { Implementation }\end{array}$ \\
\hline $\begin{array}{l}\text { Hurley and } \\
\text { Hult [1998] }\end{array}$ & $\begin{array}{l}\text { Culture } \\
\text { characteristics } \\
\text { supporting } \\
\text { innovation }\end{array}$ & $\begin{array}{l}\text { Market focus } \\
\text { Learning and development } \\
\text { Status differentials } \\
\text { Participative decision making } \\
\text { Support and collaboration } \\
\text { Power sharing } \\
\text { Communication } \\
\text { Tolerance for conflict and risk }\end{array}$ & $\begin{array}{l}\text { Market } \\
\text { Learning } \\
\text { Internal } \\
\text { cooperation } \\
\text { Risk taking and } \\
\text { creativity }\end{array}$ \\
\hline
\end{tabular}




\begin{tabular}{|c|c|c|c|}
\hline Source & $\begin{array}{l}\text { Construct } \\
\text { studied }\end{array}$ & Scale items for dimensions/measures & $\begin{array}{c}\text { Focus areas (See } \\
\text { note at the foot of } \\
\text { the table) }\end{array}$ \\
\hline $\begin{array}{l}\text { Slater et al. } \\
\text { [2014] }\end{array}$ & $\begin{array}{l}\text { Organizational } \\
\text { culture asa } \\
\text { component of } \\
\text { Radical Product } \\
\text { Innovation } \\
\text { Capability } \\
\end{array}$ & $\begin{array}{l}\text { Adhocracy } \\
\text { Customer orientation } \\
\text { Competitor orientation, } \\
\text { Technological orientation } \\
\text { Learning orientation } \\
\text { Willingness to cannibalize }\end{array}$ & $\begin{array}{l}\text { Flexibility } \\
\text { Market } \\
\text { Technology } \\
\text { Learning }\end{array}$ \\
\hline $\begin{array}{l}\text { Hogan and } \\
\text { Coote [2014] }\end{array}$ & $\begin{array}{l}\text { Organizational } \\
\text { culture that } \\
\text { supports } \\
\text { innovation }\end{array}$ & $\begin{array}{l}\text { Norms for Innovation } \\
\text { Examples: } \\
\text {-expectations of open communication about new } \\
\text { ideas and approaches to solving problems } \\
\text {-expectations of co-operation and team work } \\
\text { in developing new ideas and new ways of dealing } \\
\text { with work tasks } \\
\text { Innovative Behaviors } \\
\text { Examples: } \\
\text {-solve clients' problems in innovative ways } \\
\text {-implement innovative marketing programs } \\
\text {-innovate with software \& technology } \\
\text { Values Supporting Innovation } \\
\text { Examples: } \\
\text {-valuing open communication within the firm } \\
\text {-valuing co-operation throughout the firm. }\end{array}$ & $\begin{array}{l}\text { Internal } \\
\text { cooperation } \\
\text { Openness } \\
\text { Creativity and } \\
\text { innovation }\end{array}$ \\
\hline $\begin{array}{l}\text { Darroch and } \\
\text { Naughton } \\
{[2001]}\end{array}$ & $\begin{array}{l}\text { Knowledge } \\
\text { management } \\
\text { orientation }\end{array}$ & $\begin{array}{l}\text { Learning focus } \\
\text { Market focus }\end{array}$ & $\begin{array}{l}\text { Learning } \\
\text { Market }\end{array}$ \\
\hline $\begin{array}{l}\text { Mazur et al. } \\
\text { [2008] }\end{array}$ & $\begin{array}{l}\text { Knowledge } \\
\text { orientation }\end{array}$ & $\begin{array}{l}\text { Market focus } \\
\text { Learning focus } \\
\text { Interdepartmental cooperation } \\
\text { Technology support } \\
\text { Power sharing } \\
\text { Participative decision making } \\
\text { Innovation reward system } \\
\text { External alliances }\end{array}$ & $\begin{array}{l}\text { Market, including } \\
\text { alliances } \\
\text { Learning } \\
\text { Internal } \\
\text { cooperation } \\
\text { Innovation } \\
\text { support systems }\end{array}$ \\
\hline $\begin{array}{l}\text { Sanz-Valle } \\
\text { et al. [2011] }\end{array}$ & $\begin{array}{l}\text { Learning or } \\
\text { knowledge- } \\
\text { oriented culture }\end{array}$ & $\begin{array}{l}\text { Employee desire to improve and learn } \\
\text { Openness, autonomy or self-direction } \\
\text { Employee empowerment } \\
\text { Risk assumption and ambiguity tolerance } \\
\text { Creativity } \\
\text { Teamwork, interaction with others, open } \\
\text { dialogue } \\
\text { Long-term orientation } \\
\text { Organization commitment and mutual trust }\end{array}$ & $\begin{array}{l}\text { Learning } \\
\text { Openness } \\
\text { Empowerment } \\
\text { Creativity and } \\
\text { risk taking } \\
\text { Internal } \\
\text { cooperation } \\
\text { Long-term } \\
\text { orientation }\end{array}$ \\
\hline
\end{tabular}




\begin{tabular}{|c|c|c|c|}
\hline Source & $\begin{array}{l}\text { Construct } \\
\text { studied }\end{array}$ & Scale items for dimensions/measures & $\begin{array}{c}\text { Focus areas (See } \\
\text { note at the foot of } \\
\text { the table) }\end{array}$ \\
\hline Dobni [2008] & $\begin{array}{l}\text { Innovation } \\
\text { culture }\end{array}$ & $\begin{array}{l}\text { Innovation propensity } \\
\text { Organizational consistency } \\
\text { Organizational learning } \\
\text { Creativity and empowerment } \\
\text { Market orientation } \\
\text { Value orientation } \\
\text { Implementation context }\end{array}$ & $\begin{array}{l}\text { Creativity and } \\
\text { innovation } \\
\text { Learning } \\
\text { Market } \\
\text { Value } \\
\text { Implementation }\end{array}$ \\
\hline
\end{tabular}

Notes:

Internal cooperation was expressed in different ways including: interdepartmental cooperation, power sharing, participative decision making, knowledge exchange and sharing, organization commitment and mutual trust, teamwork, interaction with others, etc.

Creativity and risk taking includes such elements as: supportive reward system, risk assumption and ambiguity, empowerment, encouragement to experiment and implement new ideas, support for change, innovation implementation support, etc. Learning focus manifests through employees' desire to improve and learn, learning support, and openness.

S ource: own elaboration.

It is worth emphasizing that we did not ignore the importance of market focus in innovative culture, which is sometimes explicitly included in conceptual models. We do subscribe to the view that innovations are beneficial only when they support organization competitiveness, so they always have to be considered in the market context. At the same time, we share the position of Slater and Narver who assert that market orientation (which can be understood as a form of market focus culture) is an aspect of general organizational culture, and not a separate construct. Even though we did not consider it relevant to account for market orientation as a separate construct in the model for this study, the meaning contained in this concept is spread throughout the constructs of creativity and risk taking and learning focus, which is also suggested by Slater [Slater, Narver, 1995, p. 63]. In addition, the market value of innovations originated in a company will be gauged by endogenous variables in the model, such as percentage of revenues from new and modified products. In the remaining part of this section of the paper we will consider more closely the selected sub-constructs of innovative culture.

The creativity and risk taking dimension consists of two closely interconnected categories of creativity focus and risk proclivity. Addressing the relationship between innovation and creativity McLean [2005] refers to the seminal works of Angle and Amabile et al. According to these authors, creativity and innovation are two closely related constructs [Angle, 1989]. While "creativity is the generation of novel and useful ideas, primarily at the individual level" [Amabile et al., 1996], innovation is the process of distinguishing, assessing, developing and implementing these ideas in practice. "It is creativity that fuels the innovation pipeline. In order for an organization to remain relevant and to compete in pursuit of its mission, management of organizations must pay close attention to both ends of the process, generating creative ideas frequently and utilizing its innovation process 
to realize the potential value of those ideas" [p. 240]. On the other hand, risk taking is a trait that supports developing more groundbreaking innovations through a bolder creative process, with more resources involved but also an inherently higher probability of market failure. It can be argued that without tolerance for the possibility of market failure creativity is hampered by being channeled to providing only the most obvious and safest solutions. In other research, similar content could be found in the concept of openness to new ideas [Baker, Sinkula, 2009].

Learning focus, which can also be referred to as learning orientation, is widely considered to influence an organization's innovation capability and its performance [Calantone et al., 2002]. Building a learning organization requires time to modify people's attitudes, beliefs and decision taking processes [Garvin, 1993]. The literature differentiates between single-loop learning (ad hoc adaptation to a changing environment) and double-loop learning (creative learning). Creative learning means breaking free from norms and principles, which are irrelevant and unlearning certain behaviors [Nystrom, Starbuck, 1984]. Creative learning, however, should not be confused with creativity - creativity means generating new ideas, while creative learning is about preparing right conditions for this process.

Learning should be viewed as an organization-wide phenomenon, since in order to meet learning orientation objectives it is necessary to combine individual learning with organizational learning [Romme, Dillen, 1997].

There are many measures in the literature intended to represent aspects of internal collaboration. For example, Sanz-Valle et al. [2011] group them into the following categories: organization-dominant characteristics (family work relations, achievement orientation, etc), management of employees (teamwork, freedom, security of employment, etc.), organizational glue (trust, commitment, goal accomplishment, aggressiveness, etc.), and criteria of success (development of human resources, competitive market leadership, efficiency etc.)

In a number of studies [Sanz-Valle et al., 2011] internal collaboration is understood as a dimension fully characterizing a certain form of organizational culture (collaborative organizational culture). This culture is known to enhance organizational learning. Pérez López et al. [2004] investigated the degree to which collaborative culture influences organizational learning and business performance in Spanish firms. Their research suggested that collaborative culture does not itself constitute a source of competitive advantage. It needs to be supported by learning to improve competitive performance. This suggestion is in line with our proposal of encapsulating internal cooperation and organizational learning under the innovative culture construct.

\section{Open Innovation Performance}

In recent years, open innovations have been a frequent topic of interest in management and economics research. There is a vast number of studies that investigate the performance of open innovation, and in particular its in-bound kind. These methods of measuring performance are highly relevant to the current research since measuring the 
impact of organizational culture on open innovation is - in fact - about its performance in cultures with different degrees of innovativeness. Formally, innovation performance can be understood as the degree of success attained by firms in achieving goals related to new products, services and other novel solutions in business processes or management [Henard, Szymanski, 2001]. Even though a number of different metrics was used for gauging open innovation performance most of such measurement systems follows a similar structure to first identify direct effects of innovations, and then take a more general view at operational effectiveness and efficiency, and - finally - financial outcomes (for a broad overview of the current literature on innovation performance measurement and an original comprehensive measurement framework see Thai and Liao [2014]). In our approach we also follow the same pattern starting from a direct measure of performance (here, the percent of revenues from new and modified products) through more general metrics of operational success for a company (see Table 3 for a detailed list) to a financial indicator that represents the profitability of the entire firm (here, ROI). This sequence is reflected in our hypotheses where we first assume a positive link between the use of open innovation sources and the percentage of revenues from new and modified products. Then we frame our hypotheses to link open-innovation sources directly and indirectly with operational and financial performance measures. The reason for this approach - similar to previous studies - is to assess the widest possible range of effects that open innovation can induce, with the weaker effects only visible in variance of sales from new and updated goods and services, and the stronger impacts registering at the level of financial metrics for the entire business. In essence, this hierarchy of effects is intended to enhance the comprehensibility and sensitivity of the analysis.

The present study fits into a stream of research probing how contextual factors affect the ties between open innovation and business performance. Such contextual factors served as moderators of regression paths from the use of open innovation to various performance measures. Examples of contextual factors of interest to researchers are market orientation (which is often seen as a kind of organizational culture [Cheng, Huizingh, 2014]), social capital (organizational culture is part of it [Rass et al., 2013]), access to tangible and intangible resources [Garriga et al., 2013], competition intensity [Foroughi et al., 2013], and many other factors internal and external to the firm. From this point of view, innovative culture in this study can be seen as one of such moderators.

\section{Conceptual Model and Research Hypotheses}

The study aims to test the hypotheses that pertain to the way of operationalizing innovative culture and the links of this concept with relevant effectiveness and productivity metrics. 
For greater clarity, the scope of the research together with all the hypotheses was illustrated in the graph below.

FIGURE 1. Graphical model of the research concept and hypotheses

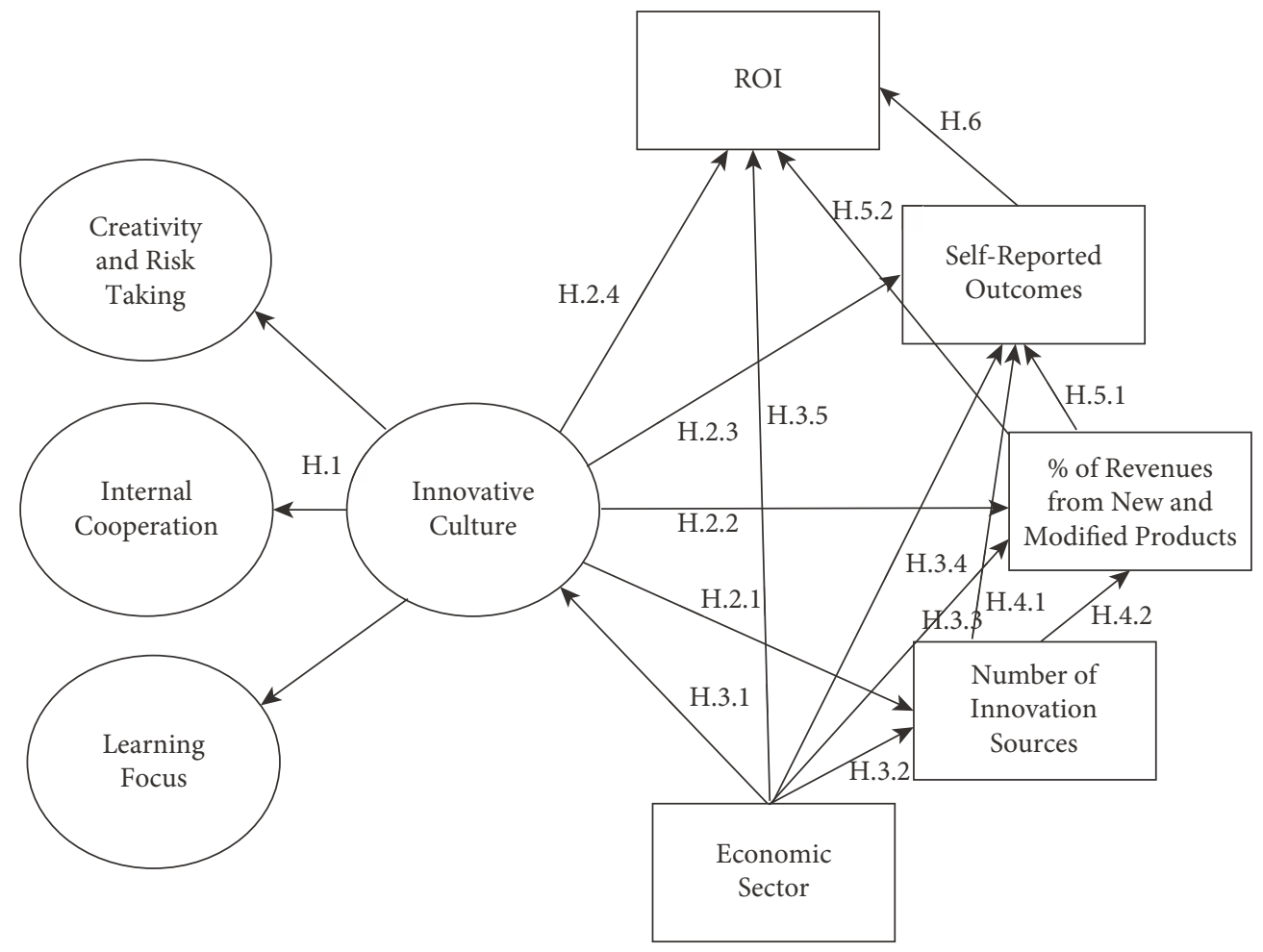

Source: own elaboration.

In particular, we propose:

H.1 Innovative culture is a second-order reflective construct measured by three first-order subconstructs of creativity and risk taking, learning focus and internal cooperation

H.2 Innovative culture is positively correlated with:

H.2.1 The number of used innovation sources

H.2.2 The percentage of revenues from new and modified products

H.2.3 Self-reported outcomes

H.2.4 ROI

H.3 There are differences between the economic sectors of manufacturing and services with regard to:

H.3.1 Innovative culture 


\section{H.3.2 The number of used innovation sources}

H.3.3 The percentage of revenues from new and modified products

H.3.4 Self-reported outcomes

H.3.5 ROI

H.4 The number of used innovation sources is positively correlated with:

H.4.1 Percentage of revenues from new and modified products

H.4.2 Self-reported outcomes

H.5 The percentage of revenues from new and modified products is positively correlated with:

H.5.1 Self-reported outcomes

H.5.2 ROI

H.6 Self-reported outcomes are positively correlated with ROI

These hypotheses were derived from the previously presented literature review and were designed to test the general research question of how the number of used innovation sources (i.e., a search scope or breadth, determining how widely a firm explores new knowledge) impacts operational and financial outcomes, controlling for the influence of innovative culture and economic sector.

The economic sector here refers to a binary classification of surveyed companies into manufacturers or service providers, both operating in B2C markets. We chose to compare these two groups of firms expecting different results in terms of interactions between organizational culture and innovativeness. Service innovation is in many companies a result of interaction with customers and direct requests from them [Victorino et al., 2005]. Although technology has enabled all companies to directly communicate with their customers in real time, first-line employees in services companies can observe customer experiences on the spot and propose dedicated service modifications, sometimes leading to company-wide innovations. Indeed, empirical research confirms the positive impact of service innovation on firm performance [Grawe et al., 2009; Hilman, Kaliappen, 2015]. Hence, economic sector serves as a control variable in our study.

\section{Construct Operationalizations}

Some of the variables used in the hypotheses cannot be measured directly and call for sets of indicators instead. Such hidden variables, also termed constructs, include innovative culture and its components (which are reflective constructs) as well as self-reported outcomes (which is a formative construct). The subsequent two tables present indicators used to ascertain the values of each construct. 
TABLE 2. Multi-item measurement scale for innovative culture

\begin{tabular}{|c|c|}
\hline Item content & $\begin{array}{l}\text { SEM model } \\
\text { designation }\end{array}$ \\
\hline \multicolumn{2}{|l|}{ Innovative culture subconstruct 1: Creativity and risk taking } \\
\hline Our managers are not afraid to take the risk of making innovations. & CREAT_1 \\
\hline $\begin{array}{l}\text { Our managers have the knowledge and vision necessary to take advantage of } \\
\text { emerging business opportunities. }\end{array}$ & CREAT_2 \\
\hline Our company can be described as an ambitious and dynamic organization. & CREAT_3 \\
\hline Our organizational culture is distinguished by the emphasis on constant innovation. & CREAT_4 \\
\hline Our employees are encouraged to "think outside the box". & CREAT_5 \\
\hline \multicolumn{2}{|l|}{ Innovative culture subconstruct 2: Learning focus } \\
\hline We believe that our organization's ability to learn is key to our market success. & LEAFO_1 \\
\hline The sense around here is that employee training is an investment and not an expense. & LEAFO_2 \\
\hline Continuous learning is seen as the main condition of our company's survival. & LEAFO_3 \\
\hline Employee growth and learning is among our top priorities. & LEAFO_4 \\
\hline \multicolumn{2}{|l|}{ Innovative culture subconstruct 3: Internal cooperation } \\
\hline $\begin{array}{l}\text { Advice from work colleagues is a common way of solving problems among employees } \\
\text { in our company. }\end{array}$ & INTCO_1 \\
\hline Sharing knowledge with work colleagues is beneficial for our employees. & INTCO_2 \\
\hline Employees from different posts or departments often cooperate in problem solving. & INTCO_3 \\
\hline
\end{tabular}

Source: own elaboration.

Relevant aspects of organizational culture were determined with a five-point Likert scale, where respondents were asked to indicate their level of agreement with each of the given statements. Scores given by respondents on individual items were later used as inputs in a confirmatory factor analysis (CFA) performed as part of the structural equation modeling. The resulting CFA allowed us to estimate the values of all first and second-order constructs and establish the reliability of the measurement model for innovative culture.

The idea behind developing the scale for self-reported outcomes was to capture possible operational effects of increased percentages of new and modified products in firm revenues. The list of operational effects comprising the index is set out in Table 3 .

It was assumed that self-reported outcomes would be placed at an intermediate level between a variable accounting for immediate effectiveness of innovation policies (i.e. the percentage of revenue generated by new and modified products) and a financial metric (here, ROI). Lack of such an intermediary could preclude successful detection of the effects of innovations, should they be weak enough to not affect ROI directly. The self-reported outcomes scale was administered as a set of dichotomous questions with "yes or no" response options. Then the composite variable was obtained (which is a frequent 
practice with formative constructs) by summing up all scores for each company ("yes" was coded as 1 and "no" as 0 ). In consequence of such a transformation, the new variable could take values from 0 to 7 , with greater scores indicating better performance.

\section{TABLE 3. Scale items for measuring self-reported operational and financial outcomes of the sampled companies}

\begin{tabular}{|l|}
\hline Our firm increased its revenues in 2013 as compared to 2012. \\
\hline Our net profit margin in 2013 was greater than in 2012. \\
\hline The number of returning customers in 2013 was greater than in 2012. \\
\hline The amount of complaints from consumers of our products in 2013 was smaller than in 2012. \\
\hline $\begin{array}{l}\text { In each of the last three years (between } 2011 \text { and 2013) our revenues grew in comparison to the previous } \\
\text { year. }\end{array}$ \\
\hline $\begin{array}{l}\text { In each of the last three years (between } 2011 \text { and 2013) our profits grew in comparison to the previous } \\
\text { year. }\end{array}$ \\
\hline $\begin{array}{l}\text { In each of the last three years (between } 2011 \text { and 2013) the amount of complaints from our customers fell } \\
\text { in comparison to the previous year. }\end{array}$ \\
\hline
\end{tabular}

S o urce: own elaboration.

Another formative construct in the model was the number of innovation sources used in a company over the three years preceding the interview. Its purpose was to establish the extent of the company's involvement in inbound open-source innovation, representing acquisition of knowledge from various actors inside and outside the company and its value chain. Index scores were obtained by counting up all innovation sources indicated by respondents from a predefined list of 14 innovations split into sources internal to the supply chain of a company (6 items), and those outside of the supply chain (8 items). Sources internal to the supply chain included: R\&D employees of a company, other employees of a company, business customers (e.g. distributors), consumers, anonymous internet users and suppliers. The other grouping consisted of: license purchases, patent purchases, technology purchases, company acquisitions and takeovers, copying competitors' solutions, contracts with universities, contracts with research institutes and contributions from consultants. This list of items was compiled primarily from the survey by Chesbrough and Brunswicker [2013]. We added a new source (imitating competitors), as we expected it to be of particular importance for SMEs. In line with van de Vrande et al. [2009], the list was complemented by the inclusion of firms' employees (from R\&D department and outside of R\&D department). 


\section{Sampling Method}

Data for this study were gathered in a CATI survey of managers in July and August 2014. The final net sample included 473 cases for a response rate of $35 \%$. Sample elements were drawn at random from a comprehensive database comprising almost every industrial and consumer company in Poland, maintained by a research agency employed to carry-out the interviews. Subsequent comparison of the net sample and population distributions on known characteristics did not reveal any statistically significant differences, which implies that the attained return rate did not compromise generalizability. The database contained validated actual financial metrics on the companies, of which ROI was used in the current study to supplement the survey results.

The sample was made up of $47.4 \%$ of manufacturing and $52.6 \%$ of service companies; $67.2 \%$ of businesses had between 10 and 50 employees and 32.8\% were medium sized firms with between 51 and 250 employees. All manufacturers were involved in food and non-alcoholic beverage production, while service companies operated in the hospitality industry (31\%), food service (56\%) or as travel and tourism agents (13\%).

\section{Research Findings}

The statistical approach to testing the hypotheses employed structural equation modeling (SEM) with the AMOS 22 statistical software, which permitted assessing the whole set of regression paths with a single statistical test. In addition, the SEM method provided individual metrics for evaluation of particular bivariate relationships.

The graphical representation of the structural model for the current study, including standardized estimates of regression weights and multiple correlation coefficients, is depicted in Figure 2.

To facilitate interpretation of the model and its components, it is worth recalling that the construct of innovative culture was assumed to be reflective in nature (the same assumption was made in every other quantitative research on innovative culture known to the authors). Since they are meant to measure the same latent variable, all three of its dimensions are supposed to be correlated with each other. The statistical procedure used in SEM identifies this common variance and computes factor scores on innovative culture for all respondents. Then the factor scores are used as input in the regression part of the structural model. Consequently, the model does not investigate the whole of each dimension of IC, but only the shared variance across dimensions, which was assumed to be a manifestation of IC. With such a model configuration it is not meaningful to try to connect individual IC dimensions to performance variables with regression paths 
- again, all that can be studied with this framework is the shared variance encapsulated in factor scores for IC.

FIGURE 2. Path diagram for the structural model of relationship between innovative culture and operational and financial outcomes, controlling for influences of innovative culture and economic sector

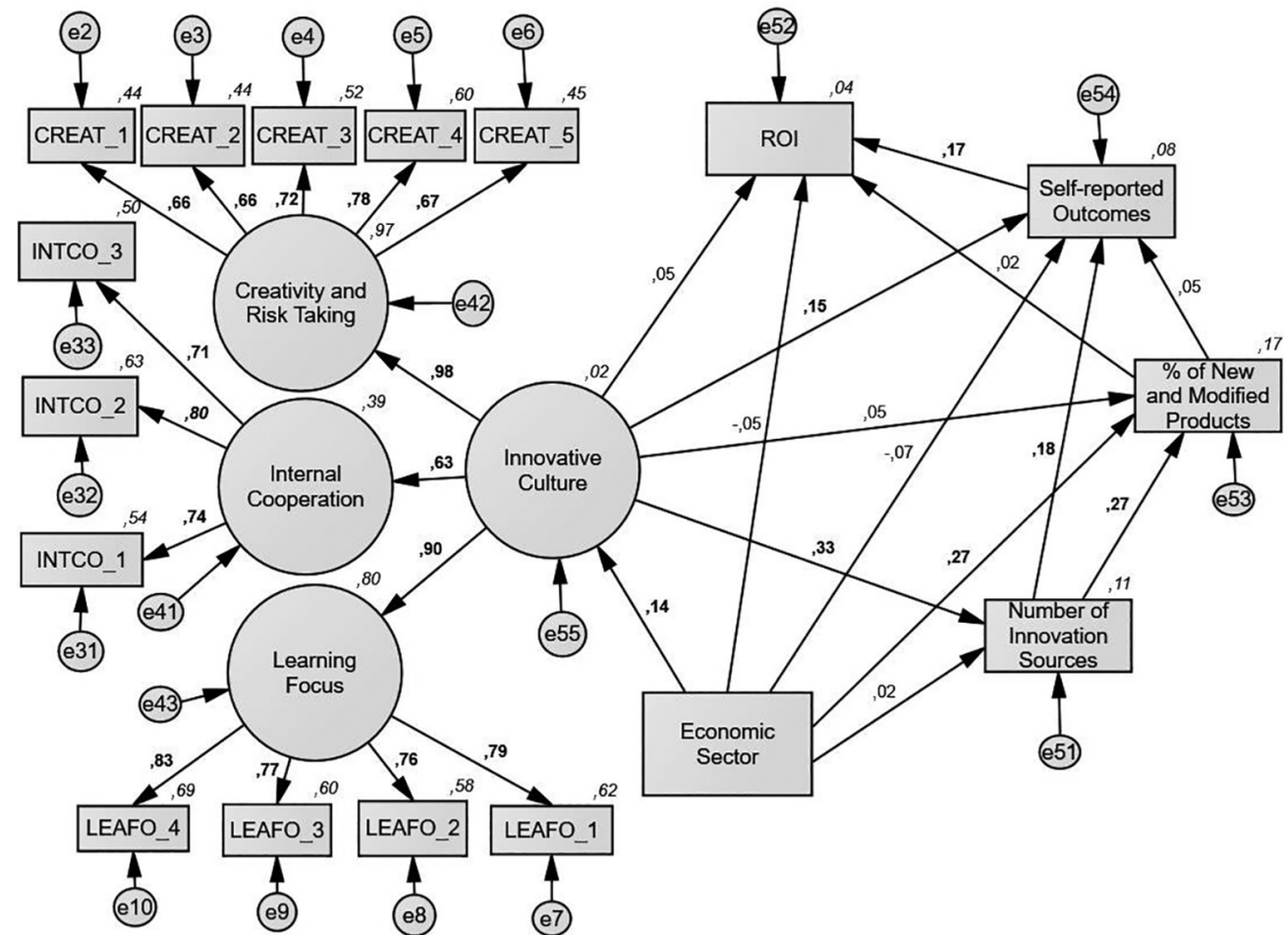

Note: statistically significant standardized regression weights were marked in bold.

S ource: own elaboration.

To assure that manufacturing and service companies could be treated as a single group to represent aspects of innovative culture, measurement invariance was assessed by comparing two nested structural models. The first general model did not include any constraints on regression weights between second and first-order constructs as well as between first-order constructs and their indicators - as such manufacturers and service providers could take different regression coefficients. The second model fixed those parameters to the same level for both types of companies. The resulting comparison yielded a difference in chi-square value of 7.945 with 9 degrees of freedom and a p-value of 0.540 . 
This outcome implies that the model with the same regression weights for the manufacturing and services firms did not provide a significantly worse data fit than allowing the parameters to change freely between the two types of companies. Consequently, all firms were pooled together in a single group and the solution with the same parameter estimates for all companies was chosen for further analysis as a simpler and more theoretically appealing method (i.e. permitting wider generalizations). Even though the measurement model was the same, the specificity of the two types of firms was accounted for in the full structural model by introducing the binary variable of economic sector to see if the type of company influenced the magnitude of innovative culture or any other outcome variable.

Before discussing specific parts of the model it is crucial to establish its general quality regarding how close it comes to accurately representing empirical data. To this end, a number of typical, overall goodness of fit measures was determined (Table 4). In a general sense, fit indices inform to what extent a model is capable of recreating the covariance matrix computed from the actual empirical data, though they take different assumptions and use varied formulas to account for various research contexts. To help in interpreting, the table contains threshold levels that - according to recommendations in the literature - distinguish well-fitting SEM solutions [Garson, 2012].

\section{TABLE 4. Overall goodness of fit measures for the model}

\begin{tabular}{|l|c|c|}
\hline \multicolumn{1}{|c|}{ Metric } & Value & Threshold for a well-fitting model \\
\hline Chi-square/df (relative chi-square) & 1.648 & $<2$ for good fit, $<3$ for acceptable fit \\
\hline p-value for the model & $<0.001$ & $>0.05$ \\
\hline GFI (goodness of fit index) & 0.953 & $\geq 0.9$ \\
\hline AGFI (adjusted goodness of fit index) & 0.933 & $\geq 0.8$ \\
\hline $\begin{array}{l}\text { RMSEA (root mean square of } \\
\text { approximation) }\end{array}$ & $\begin{array}{c}0.038 ; \\
\text { HI90=0.048 }\end{array}$ & $\begin{array}{c}\leq 0.05 \text { for good model fit; } \leq 0.08 \text { for adequate fit; } \\
\text { in addition, the upper } 90 \% \text { confidence limit }\end{array}$ \\
\hline $\begin{array}{l}\text { PCLOSE (p value for testing the null } \\
\text { hypothesis that the population RMSEA } \\
\text { is no greater then 0,05) }\end{array}$ & 0.974 & \multicolumn{1}{c|}{\begin{tabular}{c}
$\geq 0.05$ \\
\hline
\end{tabular}}
\end{tabular}

S o u r c e : own elaboration. Cutoff points based on Garson [2012].

The fit indices indicate that the structural model can be accepted as offering an adequate approximation of empirical data. One of the tests - the chi square test -appears to suggest that the solution could be lacking in accuracy, as the p score of less than 0.05 leads to rejecting the null hypothesis of no significant differences between the observed covariance matrix and the one reproduced from the model. However, the chi square test is thought to be unreliable, particularly for large sample sizes, often giving too large values 
signaling the need to reject otherwise adequately fitting models [Byrne 2010, pp. 76-77]. For that reason, a number of additional indices are available for assessing the reliability and validity of a CFA solution, relying on different features of the model fit and using various assumptions about data. In fact, "although the chi-square value should always be reported it is widely considered acceptable to conclude that a model fits the data well, even when the value is statistically significant, if other preselected fit indices meet their established criteria for fit" [Bowen, Guo, 2012, p. 142]. This is the case with the current analysis: 5 indicators alternative to the chi-square test denote a well-fitting solution, which is a strong enough reason for not rejecting the model.

The overall fit metrics do not reveal much about the reliability and validity of individual latent variables. This purpose is served by three additional metrics, computed individually for each subconstruct of the model and listed in Table 5.

TABLE5. Reliability and validity measures for component constructs of innovative culture

\begin{tabular}{|l|c|c|c|}
\hline \multicolumn{1}{|c|}{ Construct } & Cronbach's Alpha & AVE & MSV \\
\hline Innovation Focus & 0.81 & 0.49 & 0.46 \\
\hline Internal Cooperation & 0.78 & 0.56 & 0.39 \\
\hline Learning Focus & 0.86 & 0.62 & 0.46 \\
\hline
\end{tabular}

Source: own elaboration.

Cronbach's alpha is a commonly used internal reliability measure of multi-items scales, with a value of 0.6 or greater indicating one dimensional and thus consistent scales [Malhotra, 2014, p. 287]. Considering that alphas for all three factors are beyond that threshold it is fair to say that the scales for all subconstructs display adequate levels of reliability.

Convergent validity indicates to what extent a factor explains its manifest variables (i.e. indicators) and is often established with the AVE metric (AVE standing for Average Variance Extracted). It is assumed that AVE values of more than 0.5 are acceptable [Hair et al., 2010]. Seeing that two constructs have AVE values above the cut-off and one is just about the required level, it seems reasonable to conclude that the measurement part of the SEM model is characterized by an acceptable level of convergent validity.

The third important facet of quality of scales for measuring latent variables is discriminant validity, which considers the extent to which a factor is explained better by its own indicators instead of by indicators from other factors. Discriminant validity is determined by comparing AVE to MSV (maximum shared variance); it is assumed that a model is acceptable if AVE scores are greater than MSV scores for all its constructs [Hair et al., 2010]. In terms of this criterion the present model shows adequate discriminant validity.

Based on the preceding discussion it is clear that the measurement model offers a good fit across all relevant diagnostic metrics, which gives support to H.1. 
Continuing with the analysis of the model, the next step was focused on its structural part, consisting of regression paths among innovative culture, number of innovation sources, economic sector, and operational and financial performance metrics. The path diagram shows standardized regression coefficients (betas), which could be interpreted in a similar manner to Pearson correlation coefficients. Betas that indicate statistically significant relationships were written in bold type. Another set of numerical values contained in the chart are squared multiple correlations, which are put in italics in the upper-right corner of each endogenous variable and provide the percentage of variance in a given variable that is explained by all predictors in the model. The significance of model betas can be used for testing the hypotheses.

Even though the hypotheses could be easily verified by looking at the graph it is admittedly more convenient to set out all relevant regression paths in a table together with their betas, $\mathrm{p}$-values, hypothesis symbols and verification outcomes, which is provided in Table 6.

From the strength and significance of direct effects displayed in the table 6 , half of the propositions (7 out of 14) were not supported by empirical data. It should be noted, though, that direct effects explicitly do not take into consideration indirect effects, which are possible influences that variables can exert through other mediating variables.

\section{TABLE6. Hypothesis verification table based on significance of direct effects}

\begin{tabular}{|l|l|c|c|c|c|}
\hline \multicolumn{1}{|c|}{ Predictor variable } & \multicolumn{1}{|c|}{ Outcome variable } & Beta & p-value & Hypothesis & $\begin{array}{c}\text { Verification } \\
\text { outcome } \\
\text { 1: supported } \\
\text { 0: falsified }\end{array}$ \\
\hline innovative culture & $\begin{array}{l}\text { number of used innovation } \\
\text { sources }\end{array}$ & .330 & $<.001$ & H.2.1 & 1 \\
\hline innovative culture & $\begin{array}{l}\text { percentage of revenues from } \\
\text { new and modified products }\end{array}$ & .050 & .333 & H.2.2 & 0 \\
\hline innovative culture & self-reported outcomes & .148 & .008 & H.2.3 & 1 \\
\hline innovative culture & ROI & .050 & .354 & H.2.4 & 0 \\
\hline economic sector & innovative culture & .139 & .009 & H.3.1 & 1 \\
\hline economic sector & $\begin{array}{l}\text { number of used innovation } \\
\text { sources }\end{array}$ & .016 & .737 & H.3.2 & 0 \\
\hline economic sector & $\begin{array}{l}\text { percentage of revenues from } \\
\text { new and modified products }\end{array}$ & .268 & $<.001$ & H.3.3 & 1 \\
\hline economic sector & self-reported outcomes & -.075 & .132 & H.3.4 & 0 \\
\hline economic sector & ROI & -.049 & .334 & H.3.5 & 0 \\
\hline $\begin{array}{l}\text { number of used innovation } \\
\text { sources }\end{array}$ & $\begin{array}{l}\text { percentage of revenues from } \\
\text { new and modified products }\end{array}$ & .268 & $<.001$ & H.4.1 & 1 \\
\hline $\begin{array}{l}\text { number of used innovation } \\
\text { sources }\end{array}$ & self-reported outcomes & .177 & $<.001$ & H.4.2 & 1 \\
\hline
\end{tabular}




\begin{tabular}{|l|l|c|c|c|c|}
\hline \multicolumn{1}{|c|}{ Predictor variable } & \multicolumn{1}{|c|}{ Outcome variable } & Beta & p-value & Hypothesis & $\begin{array}{c}\text { Verification } \\
\text { outcome } \\
\text { 1: supported } \\
\text { 0: falsified }\end{array}$ \\
\hline $\begin{array}{l}\text { percentage of revenues from } \\
\text { new and modified products }\end{array}$ & self-reported outcomes & .051 & .322 & H.5.1 & 0 \\
\hline $\begin{array}{l}\text { percentage of revenues from } \\
\text { new and modified products }\end{array}$ & ROI & .015 & .767 & H.5.2 & 0 \\
\hline self-reported outcomes & ROI & .171 & $<.001$ & H.6 & 1 \\
\hline
\end{tabular}

Source: own elaboration.

Innovation culture, though significantly and positively linked to the number of used innovation sources, did not have any meaningful bearing on how successfully those innovations were introduced into the market. However, accounting for indirect effects, with the number of used innovation sources as the moderator, the total amount of effect size grew from a beta of. 05 to. 14 , which is statistically significant. Thus, the presence of indirect effects gave Hypothesis 2.2 partial support.

Organizations with more innovative cultures did show better operational performance, as measured by Self-Reported Outcomes. Apparently, the construct did not have a direct relationship with ROI, as this regression path was insignificant, but after accounting for the mediation of other variables the total effect of Innovative Culture on ROI is positive and significant, though weak (beta $=.089$; $\mathrm{p}$-value (based on bootstrap estimates) $=.048$ ). This could be considered as a partial confirmation of Hypothesis 2.4

\section{Discussion and Conclusions}

The analysis revealed some interesting discrepancies and similarities between manufacturers and service companies. Specifically, services firms had a stronger innovative culture and a higher percentage of revenues from new and modified products. On the other hand, the two groups of businesses were practically indistinguishable - even with indirect effects factored in - in terms of the scope of used innovation sources, self-reported outcomes and ROI.

Interestingly, companies with greater proportions of revenues from the sales of new and modified products did not show better operational or financial performance. However, involvement in OI seemed to positively affect operational performance through a direct path from the variable number of used innovation sources to self-reported outcomes.

The outcomes of SEM seem to point to a positive but rather complex role of innovative culture and involvement in OI. It seems that new and modified products might not necessarily be more profitable than the older ones. However, the available data cannot reveal 
what the profitability would be if those novel offerings were not launched into the market; it might have just as well been that new and altered products did not increase competitive advantage but were instrumental in maintaining current levels of competitiveness. This explanation is made more plausible by the fact that both sectors are operating in markets where competition is rather fierce and expected product lifespan relatively short.

Another possible explanation for the apparent lack of connection between revenues from innovative products and financial and operational performance is the nature of product innovations reported by our sample of firms. The metric used in the questionnaire did not differentiate between innovations in terms of how novel or radical they were - a wide range of changes and modifications to offerings were considered product innovations. In comparison, Baker and Sinkula [2002] distinguish three types of product innovations based on the interplay of market and learning orientations in a company:

1. Innovation through modeling limited to manager-driven incremental innovation;

2. Market-driven incremental innovation resulting from adaptive learning;

3. Ongoing radical innovation as a consequence of higher-order learning challenging existing views of the marketplace (so called generative learning).

It seems likely that a large percentage of revenues from new and modified products reported by Polish SMEs concerned the two first categories. They involved rather small "skin-deep" changes that were probably not consequential for the competitive advantage of a company. Following this reasoning one could conclude that any product innovations are not enough for business success - instead, they ought to offer consumers original and meaningful features and utilities to make a difference.

On the other hand, the data seem to provide evidence that the organization capable of effectively learning and quickly innovating can at least benefit indirectly from various enhanced efficiencies, which is indicated by significant positive effects of innovative culture and the number of used innovation sources on self-reported outcomes. Also, ROI - which was the only measure in the model not having originated from the survey interviews, but from a separate and validated database with financial metrics - appeared to be augmented in businesses with more innovation-minded cultures through the joint impact of direct and indirect effects.

Comparing our outcomes with earlier research by other authors it is possible to find both similarities and contrasts, but - most importantly - referring to previous works helps better understand some of the patterns found in our data. First of all, most of the research supports the claim that innovative culture tends to lead to more innovations, however often they are not product innovations. As an example, Škerlavaj et al. [2010] found that the organizational learning culture (which was one of the sub-dimensions of innovative culture in our study) leads to more innovations, especially of technical and administrative kind. In a recent study, Ali and Park [2016] confirmed the positive effects of innovative culture on process and management innovations but not on product innovations, where the association was insignificant. A similar effect may also be found in our study, where 
higher levels of innovative culture correspond with a greater number of innovation sources used, but fail to translate into a larger percentage of revenues from new and modified products; this could be due to most of the innovations fostered by organizational culture being of a managerial and process kind, which were not directly investigated in our research. Indeed, those unobserved managerial and process innovations could account for significant total effects between innovative culture and metrics of operational and financial performances in our study.

Another insight can be gained from a study by Toaldo et al. [2013] who explored ties between innovative culture, marketing strategy process and organizational performance. There, the construct of marketing research process comprised a number of good practices expressed as Likert scale items. Interestingly, Toaldo and colleagues obtained an insignificant direct regression path from innovative culture to performance, but there was a considerable indirect effect on performance through marketing processes. This could be interpreted as innovative culture stimulating process or marketing innovations resulting in adopting more of practices, rather than working through product innovations.

More corroborating evidence for such an understanding can be found in another study on the topic of the innovation - performance relationship in commercial banks. Damanpour and Gopalakrishnan demonstrated that "high-performance banks adopted product and process innovations more evenly than low-performance banks" [2001, p. 45]. This suggests that product innovation is not the only innovation type that meaningfully supports organization performance. In a follow up longitudinal study this proposition was more deeply probed using a larger sample of public organizations instead of banks, concluding that the impact of innovation on organizational performance depends on the composition of innovation types (service, technological process, and administrative process) over time. Organizations that kept on adjusting their respective innovation sets to meet future market challenges had superior performance [Damanpour et al., 2005]. This further supports the notion that product innovations must be underpinned by other types of innovations to improve the odds of success.

Additional explanations for the apparent lack of influence of innovative culture on sales from innovative products are found in the work of Chatzoudes et al. [2015] who observed a positive relationship between innovative culture and knowledge creation and diffusion in organizations - this beneficial effect, however, tends to be slow in improving product innovations. Considering that our survey was cross-sectional and not longitudinal, we had no way of observing the time lag between developing innovative culture and its effects on new product sales - this unaccounted-for time lag could be a confounding factor rendering this regression path insignificant.

Cheng and Huizingh [2014] in their survey of 223 Asian services firms found strategic orientation to be a significant and positive moderator between open innovation and innovative performance with entrepreneurial orientation strengthening the positive effect more than market or resource orientation. Considering that the key factors distinguishing 
entrepreneurial orientation are proactiveness, risk tolerance, creativity and intensive support for innovation process, it seems that there is a marked overlap with our own concept of innovative culture. As such, these outcomes are consistent with our findings, and strengthen our results by showing that similar patterns are detectable in other geographical and industrial contexts.

The above discussion highlights some of the limitations of our research, in particular the absence of measures of other, non-product innovations (e.g. process, marketing, and administrative), which could show stronger associations with innovative culture, and the lack of data points for sufficiently long historical periods enabling us to identify those effects of innovative culture that take longer to manifest. Our study was also constrained by not distinguishing between radical and minor innovations, which could reveal new data patterns. Further research on the topic should address these design issues. Another aspect not studied in this paper is employees' perceptions of an innovation-supportive culture in terms of management support, organizational reward system, workload pressures and other pertinent considerations. According to Chandler [1993], "some organizations perform better when key employees believe they are rewarded for being innovative, while other organizations perform better when key employees believe they are rewarded conforming to the rules and not being very innovative" [Chandler et al., 2000, pp. 59-60]. This confusing role of a reward system conceivably explains some of the variance in innovation performance not accounted for by our current model, and might be addressed in follow-up research.

In terms of practical implications, the study yielded the following guidelines and recommendations to managers and other practitioners:

- The lack of links between revenues from new and modified products and performance metrics suggests that maximizing product innovations should not always be a prioritized strategic option, at least not for companies that are looking to maximize operational effectiveness and boost profits. It appears that not all product modifications support these objectives.

- Firms with more innovative cultures tended to use more innovation sources, had better self-reported outcome index (measuring mostly operational level performance) and - through a combination of direct and indirect effects - ROI. It is therefore meaningful for managers to appreciate that innovative culture is advantageous not only because of its possible influence on product innovations, but perhaps even more so through its stimulating effects on administrative, marketing and process innovations, which are the most likely source of the reported improved operational and financial outcomes. Beneficial effects from these non-product innovations can include increased flexibility, improved cooperation, better knowledge absorption, and other efficiencies in many functional areas of a firm. 


\title{
Acknowledgment
}

\author{
The research was financed by the Polish Ministry of Science and Higher Education \\ grant KGS/S/14/2014.
}

\section{Notes}

1 Author’s e-mail address:jolanta.mazur@sgh.waw.pl

2 Author's e-mail address: piotr.zaborek@sgh.waw.pl (corresponding author)

\section{References}

Alavi, M., Kaywortth, T.R., Leidner, D.E. (2005), An Empirical Examination of the Influence of Organizational Culture on Knowledge Management Practices, Journal of Management Information Systems, Vol. 22, No. 3, pp. 191-224.

Al Saifi, S. (2015), Positioning organizational culture in knowledge management research, Journal of Knowledge Management, Vol. 18, No. 2, pp. 164-189.

Ali, M., Kichan, P. (2016), The mediating role of an innovative culture in the relationship between absorptive capacity and technical and non-technical innovation, Journal of Business Research, Vol. 69, pp. 1669-1675.

Amabile, T.M., Conti, R., Coon, H., Lazenby, J., Herron, M. (1996), Assessing the work environment for creativity, Academy of Management Journal, Vol. 39, No. 5, pp. 1154-1185.

Angle, H.L. (1989), Psychology and organizational innovation, in: A.H. Van de Ven, H.L. Angle, M.S. Poole (eds.), Research on the management of innovation: The Minnesota studies, New Yok, Harper \& Row, pp. 135-170.

Arthur D. Little's UK (2008), Innovation culture: maintaining a strong innovation culture during a downturn, Arthur D. Little's UK Technology and Innovation Management Practice, available at: www.adl.com/innovationculture Baker, W.E., Sinkula, J.M. (1999), The Synergistic Effect of Market Orientation and Learning Orientation on Organizational Performance, Journal of Academy of Marketing Science, Vol. 27, No. 4, pp.411-427.

Baker, W.E., Sinkula, J.M. (2009), The complementary effect of market orientation and entrepreneurial orientation on profitability in small business, Journal of Small Business Management, Vol.47 No.4, pp. 443-464.

Baker, W.E., Sinkula, J.M. (2002), Market Orientation, Learning Orientation and Product Innovation: Delving into the Organization's Black Box, Journal of Market-Focused Management, Vol. 5, No. 1, pp. 5-23.

Barney, J. (1986), Organizational culture: Can it Be a source of Sustained Competitive Advantage?, Academy of Management Review, 11 (July), pp. 656-665.

Bowen, N., Guo, S. (2012),Structural Equation Modeling: Pocket Guides to Social Research Methods, Oxford University Press, New York. 
Bullinger, H.-J., Auernhammer, K., Gomeringer, A. (2004), Managing innovation networks in the knowledge-driven economy, International Journal of Production Research, Vol. 42, No.17, pp. 3337-3353.

Byrne, B. (2010), Structural Equation Modeling with AMOS: Basic Concepts, Applications and Programming, Second Edition, Routledge, New York.

Calantone, R.J., Cavusgil, S.T., Zhao, Y. (2002), Learning orientation, firm innovation capability, and firm performance, Industrial Marketing Management, Vol. 31, No.6, pp. 515-524.

Cameron, K., Quinn, R. (1999), Diagnosing and Changing Organizational Culture. Based on the Competing Values Framework, Addison-Wesley, Boston, MA.

Chandler, G. (1993), Reward perceptions and the performance of emerging technology dependent and non-technology dependent manufacturing firms, Journal of High Technology Management Research, Vol. 4, No. 1, pp. 63-76. Chandler, G.N., Keller, Ch., Lyon, D.W. (2000), Unraveling the Determinants and Consequences of an Innovation-Supportive Organizational Culture, Entrepreneurship: Theory and Practice, Fall, No. 59, pp. 59-76.

Chang, Ch.L-h, Lin, T-C. (2015), The role of organizational culture in the knowledge management process, Journal of Knowledge Management, Vol. 19, No. 3, pp. 433-455.

Cheng, C., Huizingh, E. (2014), When Is Open Innovation Beneficial? The Role of Strategic Orientation, Journal of Product Innovation Management, Vol. 31, No. 6, pp. 1235-1253.

Chatzoudes, D., Chatzoglou, P., Vraimaki, E. (2015), The central role of knowledge management in business operations, Business Process Management Journal, Vol. 21, No. 5, pp. 1117-1139.

Chesbrough, H. (2003a), Open Innovation: The New Imperative for Creating and Profiting from Technology, Harvard Business School Press, Boston.

Chesbrough, H.W. (2003b), Open Innovation: The New Imperative for Creating and Profiting from Technology, Harvard Business School Press, Boston, MA.

Chesbrough, H., Brunswicker, S. (2013), Executive Survey on Open Innovation 2013, available at:http://openinnovation.berkeley.edu/managing-open-innovation-survey-report.pdf, accessed: September 1, 2014.

Chesbrough, H., Vanhaverbeke, W., West, J. eds. (2006), Open Innovation: Researching a New Paradigm, Oxford University Press, New York.

Conrad, C., Poole, M. (2012), Strategic organizational communication in a global economy (7th ed.), Preface, Belmont, CA, Thomson, Wadworth.

Damanpour, F., Gopalakrishnan, S. (2001), The dynamics of the adoption of product and process innovation in organizations, Journal of Management Studies, Vol. 38, No. 1, pp. 45-65.

Damanpour, F., Walker R.M., Avellaneda, C.N. (2005), Combinative Effects of Innovation Types and Organizational Performance: A Longitudinal Study of Service Organizations, Journal of Management Studies, Vol. 46, pp. 650-675.

Darroch, J., Mc Naughton, R. (2001), Developing a Measure of Knowledge Management, in: N. Brontis (ed.), World Congress on Intellectual Capital Readings, Butterworth Heinemann, Boston.

De Long, D. (1997), Building the Knowledge-Based Organization: How Culture Drives Knowledge Behaviors, Working Paper, Center for Business Innovations, Ernst\&Young.

DeLong, D., Fahey, L. (2000), Diagnosing cultural barriers to knowledge management, Academy of Management Executive, Vol. 14, No. 4, pp. 113-127.

Denison, D. (1984), Bringing corporate culture to the bottom line, Organizational Dynamics, Vol. 13, No. 2, pp. 4-22.

Denison, D. (1990), Corporate culture and organizational effectiveness, New York: John Wiley \& Sons.

Denison, D. (1996), What IS the difference between organizational culture and organizational climate? A native's point of view on a decade of paradigm wars, Academy of Management Review, Vol. 21, No. 3, pp. 619-654. 
Denison, D., Mishra, A. (1995), Toward a theory of organizational culture and effectiveness, Organizational Science, Vol. 6, No. 2, pp. 204-223.

Denison, D. Janovics, J., Young, J., Cho, H.J. (2006), Diagnosing Organizational Cultures: Validating a Model and Method, available at: http://astadipangarso.staff.telkomuniversity.ac.id/wp-content/uploads/sites/59/2014/05/denison-2006-validity_0.pdf, accessed: July 2, 2016. Denison, D. (2000), Organizational culture: Can it be a key lever for driving organizational change? in S. Cartwright, C. Cooper (eds.), The Handbook of Organizational Culture, London, John Wiley \& Sons.

Deshpande, R., Jarley, U., Webster, F. (1993), Corporate culture, customer orientation, and innovativeness in Japanese firms: a quadrat analysis, TheJournal of Marketing, Vol. 57, No. 1, pp. 23-37.

Deshpandé, R., Webster, Jr.,F.E. (1989), Organizational Culture and Marketing: Defining the Research Agenda, The Journal of Marketing, Vol. 53, No. 1, pp. 3-15.

Dobni, C.B. (2008), Measuring innovation culture in organizations: The development of a generalized innovation culture construct using exploratory factor analysis, European Journal of Innovation Management, Vol. 11, No. 4, pp. 539-559.

Donate, M.J., Guadamillas, F. (2011), Organizational factors to support knowledge management and innovation, Journal of Knowledge Management, Vol. 15, No. 6, pp. 890-914.

Enkel, E., Gassmann, O. (2008), Driving open innovation in the front end. The IBM case, Working Paper,University of St. Gallen and Zeppelin University, St Gallen and Friedrichshafen.

Enkel, E., Gassmann, O. (2010), Creative imitation: exploring the case of cross-industry innovation, $R \& D$ Management, Vol. 40, No. 3, pp. 256-270.

Fey, C., Denison, D.R. (2003), Organizational culture and effectiveness: Can an American theory be applied in Russia?, Organization Science, Vol. 14, No. 6, pp. 686-706.

Flynn, F., Chatman, J. (2000), Strong cultures and innovation: Oxymoron or opportunity? in: C. Cooper, S.

Cartwright, C. Earley (eds.), The International Handbook of Organizational Culture and Climate, New York: John Wiley \& Sons, pp. 263-288.

Foroughi, A., Buang, N.A., Senik, Z.C., Hajmirsadeghi, R.S., Bagheri, M.M. (2015), The role of open service innovation in enhancing business performance: the moderating effects of competitive intensity, Current Science, Vol. 109, No. 4, pp. 691-698.

Garriga, H., von Krog, G., Spaeth, S. (2013), How constraints and knowledge impact open innovation, Strategic Management Journal, Vol. 34, pp. 1134-1144.

Garson D. (2012),Structural Equation Modeling: Statistical Association Publishing Blue Book Series, Statistical Association Publishing, Asheboro,

Garvin, D.A. (1993), Building a Learning Organization, Harvard Business Review, July-August, Vol. 71.

Gassman,O., Enkel, E., Chesbrough, H. (2010), The future of open innovation, R\&D Management, Vol. 40, No. 3, pp. 213-221.

Gorman, L. (2007), Corporate culture, Management Decision, Vol. 27, No. 1, pp. 14-20.

Grawe, S., Chen, H., Daugherty, P. (2009), The relationship between strategic orientation, service innovation and performance, International Journal of Physical Distribution and Logistics Management, Vol. 39, No. 4, pp. 282-300. Guan J., Ma, N. (2003), Innovative capability and export performance of Chinese firms, Technovation, Vol. 23, No. 9, pp. 737-747.

Gunday, G., Ulusoy, G., Kilic, K., Alpkan, L. (2011), Effects of innovation types on firm performance,International Journal of Production Economics, Vol. 133, No. 2, pp. 662-676. Hair, J.F., Black, W, Babin, B., Anderson, R. (2009),Multivariate Data Analysis, 7th edition, Pearson Prentice Hall, Upper Saddle River, New Jersey. 
Hatch, M. (1993), The dynamics of organizational culture, Academy of Management Review, Vol. 18, No. 4, pp. 657-694.

Henard, D., Szymanski, D (2001), Why some new products are more successful than others, Journal of Marketing Research, Vol. 38, pp. 362-75.

Herkema, S. (2003), A complex adaptive perspective on learning within innovation projects, The Learning Organization, Vol. 10, No. 6, pp. 340-346.

Higgins, J. McAllaster, C. (2002), Want innovation? Then use cultural artifacts that support it, Organizational Dynamics, Vol. 31, pp.74-84.

Hilman, H., Kalappen, N. (2015), Innovation strategies and performance: are they truly linked? World Journal of Entrepreneurship, Management and Sustainable Development, Vol. 11, No. 1, pp.48-63.

Hofstede, G., Neijen, B., Ohayv, DF.D., Sander, G. (1990), Measuring organizational cultures: a qualitative and quantitative study across twenty cases, Administrative Science Quarterly, Vol. 35, No. 2, pp. 286-316.

Homburg, Ch., Pflesser, Ch. (2000), A Multiple-Layer Model of Market-Oriented Organizational Culture: Measurement Issues and Performance Outcomes, Journal of Marketing Research, Vol. 37, No. 4, pp. 449-462.

Huang, H.-Ch, Lai, M.-Ch., Lin, L.-H., Chen, Ch.-T. (2013), Overcoming Organizational Inertia to Strengthen Business Model Innovation, Journal of Organizational Change Management, Vol. 26, No. 6, pp. 997-1002.

Huinzingh, E.K. (2011), Open innovation: State of art and future perspectives, Technovation, Vol. 31, No. 1, pp. 2-9. Hurley, R.F., Hult, G.T.M. (1998), Innovation, Market Orientation, and Organizational Learning: An Integration and Empirical Examination, The Journal of Marketing, Vol. 62 (July), pp. 42-54.

Hult, G.T., Hurley, R.F.,Knight, G.A. (2004), Innovativeness: Its antecedents and impact on business performance, Industrial Marketing Management, Vol. 33, No. 5, pp. 429-438.

Janz, B.D., Prasarnphanich, P. (2003), Understanding the Antecedents of Effective Knowledge Management: The Importance of a Knowledge-Centered Culture, Decision Sciences, Vol. 34, No. 2, pp. 351-384.

Inauen, M., Schenker-Wicki, A. (2011), The impact of outside-in open innovation on innovation performance, European Journal of Innovation Management, Vol. 14, No. 4, pp. 496-520.

Jamrog, J., Vickers, M., Bear, D. (2006), Building and sustaining a culture that supports innovation, Human Resource Planning, Vol. 29, No. 3, pp. 9-19.

Jassawalla, A.R., Sashittal, H.C. (2002), Cultures that support product innovation processes, Academy of Management Executive, Vol. 16, pp. 42-53.

Katila, R., Ahuja, G. (2002), Something old, something new: A longitudinal study of search behavior and new product introduction, Academy of Management Journal, Vol. 45, No. 6, pp. 1183-1194.

Koc, T., Ceylan, C. (2007), Factors impacting the innovative capacity in large-scale companies, Technovation, Vol. 27, No. 3, pp. 105-114.

Laforet, S. (2015), Effect of organizational culture on organizational innovation performance in family firms, Journal of Small Business and Enterprise Development, Vol. 22, No. 2, pp. 379-407.

Laursen, K., Salter, A. (2006), Open for innovation: the role of openness in explaining innovation performance among UK manufacturing firms, Strategic Management Journal, Vol. 27, No. 2, pp.131-150.

Lettl, C., Herstatt, C.,Gemuenden, H.G. (2006), Users' contributions to radical innovation: evidence from four cases in the field of medical equipment technology, R\&D Management, Vol. 36, No. 3, pp. 251-272.

Lichtenthaler, U. (2009), Outbound open innovation and its effect on firm performance: examining environmental influences, R\&D Management, Vol. 39, No. 4, pp. 317-330.

Malhotra, N. (2010), Marketing Research: An Applied Orientation, Prentice Hall, 6th edition.

Martins, E.C., Terblanche, F. (2003), Building organizational culture that stimulates creativity and innovation, European Journal of Innovation Management, Vol. 6, No. 1, pp. 64-74. 
Mazur, J., Rószkiewicz, M., Strzyżewska, M. (2008), Orientacja na wiedzę a wyniki ekonomiczne przedsiębiorstwa (Knowledge orientation vs firms performance), Warsaw School of Economics, Warsaw.

Mazur, J., Rószkiewicz, M., Strzyżewska, M. (2011), Kompozycja działań związanych z wiedzq a wyniki ekonomiczne przedsiębiorstwa (Knowledge activities composition impact on firm's performance), Warsaw School of Economics, Warsaw.

Mazur, J., Zaborek, P. (2015), Open Innovation in Small and Medium-Sized Polish Enterprises, in: M.A. Weresa, (ed.), Poland. Competitive Report, 2015, World Economy Research Institute, Warsaw School of Economics, Warsaw. McCracken, J. (2006), "Why forward" requires culture shift at Ford, Wall Street Journal, January 23, B1.1

McDermott, R., O’Dell, C. (2001), Overcoming culture barriers to sharing knowledge, Vol. 5, No. 1, pp. 76-85. McLean, L. (2005), Organizational culture's influence on creativity and innovation: a review of the literature and implications for human resource development, Advances in Developing Human Resources, Vol. 7, No. 2, pp. 226-246.

Mulaik, S. (2009), Linear Causal Modeling with Structural Equations, Chapman \& Hall, CRC Press Taylor and Francis Group, Boca Raton.

Naranjo-Valencia, J.C., Jiménez-Jiménez, D., Sanz-Valle, R. (2011), Innovation or imitation? The role of organizational culture, Management Decision, Vol. 49, No.1, pp. 55-72.

Nystrom, P.C., Starbuck, W. (1884), To Avoid Organizational Crises, Unlearn, Organizational Dynamics, Vol. 13, Spring, pp. 53-65.

Oliver, S., Kandadi,K.R. (2006), How to develop knowledge culture in organizations? A multiple case study of large distributed organizations, Journal of Knowledge Management, Vol. 10, No. 1, pp. 6-24.

Penrose, E.T. (1959), The Theory of Growth of the Firm, Oxford University Press, New York, NY.

Pérez López, S, Montes Peón, J.M., Vázquez Ordás, C.J. (2004), Managing knowledge: the link between culture and organizational learning, Journal of Knowledge Management, Vol. 8, No. 6, pp. 93-104.

Piller F.T., Walcher D. (2006), Toolkits for idea competitions: a novel method to integrate users in new product development, R\&D Management, Vol. 36, No. 3, pp. 307-318.

Prahalad, C. K, Ramaswamy, V. (2004), The Future of Competition: Co-creating Unique Value with Customers, Harvard Business School Publishing, Boston.

Rass, M., Dunbach, M., Danzinger, E., Bullinger, A.C., Moeslein, K.M. (2013), Open Innovation and Firm Performance: The Mediating Role of Social Capital, Creativity and Innovation Management, Vol. 22, No. 2, pp. 177-194.

Riivari, E., Lämsä, A.-M., Kujala, J., Heiskanen, E. (2012), The ethical culture of organizations and organizational innovativeness, European Journal of Innovation Management, Vol. 15, No. 3, pp. 310-331.

Romme, G., Dillen, R. (1997), Mapping the landscape of organizational learning, European Management Journal, Vol. 15, No. 1, pp. 68-78.

Ruppel, C.P., Harrington, S.J. (2002), Sharing knowledge through intranets: a study of organizational culture and intranet implementation, The IEEE Transactions on Professional Communication, Vol. 44, No. 1, pp. 37-52. Hogan, S.J., Coote, L.V. (2014), Organizational culture, innovation, and performance: A test of Schein's model, Journal of Business Research, No. 67, pp. 1609-1621.

Santos-Vijande,M.L. González-Mieres, C. (2013), An assessment of innovativeness in KIBS:implications on KIBS co-creatiom culture, innovation capacity, and performance, Journal of Businesse Industrial Marketing, Vol. 28, No. 2, pp. 86-102.

Sanz-Valle., R., Naranjo-Valencia, J.C.,Jiménez-Jiménez, D., Perez-Caballero, L. (2011), Linking organizational learning with technical innovation and organizational culture, Journal of Knowledge Management, Vol. 15, No. 6, pp. 997-1015.

Schein, E. (1992), Organizational culture and leadership, San Francisco, CA, Jossey-Bass. 
Schwartz, H, Davis, S.M. (1981), Matching Corporate Culture and Business Strategy, Organizational Dynamics, Vol. 10, No. 2, pp. 30-48.

Sharifirad, M.S., Ataei, V. (2012), Organizational culture and innovation culture: exploring the relationships between constructs, Leadership \& Organization Development Journal, Vol. 33, No. 5, pp.494-517.

Simpson, P.M., Siguaw, J.A., Enz, C.A. (2006), Innovation orientation outcomes: the good and the bad, Journal of Business Research, Vol. 59, No. 10-11, pp. 1133-1141.

Skerlavaj, M., Hoon Song, J. (2010), Organizational culture, innovative culture and innovations in South Korean firms, Expert Systems and Applications, Vol. 37, pp. 6390-6403.

Slater, S., Narver, J.C. (1995), Market Orientation and the Learning Organization, The Journal of Marketing, No. 59 (July), pp. 63-74.

Slater, S.F., Mohr, J.J., Sengupta S. (2014), Radical Product Innovation Capability: Literature Review, Synthesis, and Illustrative Research Propositions, Journal of Product Innovation Management, Vol. 31, No. 3, pp. 552-566. Smircich, L. (1983), Concepts of Culture and Organizational Analysis, Administrative Science Quarterly, 28 (September), pp. 339-358.

Theyel, N. (2012), Extending open innovation throughout the value chain by small and medium-sized manufacturers, International Small Business Journal, Vol. 31, No. 3, pp. 256-274.

Toaldo M., Didonet R., Luce, F. (2013), The influence of innovative organizational culture on marketing strategy formulation and results, Latin American Business Review, Vol. 14, pp. 251-269.

Tsai, C. T, Liao, W.F. (2014), A framework for open innovation assessment, International Journal of Innovation Management, Vol. 18, No. 1 pp. 1-28.

Van de Vrande, V., de Jong, J.P.J., Vanhaverbeke, W., de Rochemont, M. (2009), Open Innovation in SMEs: Trends, Motives and Management Challenges, Technovation, Vol. 20, pp. 423-437.

Van Hemert, P., Njikamp, P., Masurel, E. (2013), From innovation to commercialization through networks and agglomerations: analysis of sources of innovation, innovation capabilities and performance of Dutch SMEs, Annals of Regional Science, Springer Science \& Business Media B.V., 50, pp. 425-452, DOI 10.1007/s00168-012-0509-1. Vargo, S.L., Lusch, R.F. (2004), Evolving to a new dominant logic for marketing, The Journal of Marketing, Vol. 68 (January), pp. 1-17.

Verhees, F.J.H. M., Meulenberg, M.T.G. (2004), Market Orientation, Innovativeness, Product Innovation, and Performance in Small Firms, Journal of Small Business Management, Vol. 42. No. 2, pp. 143-154.

Victorino, L., Verma, R., Plaschka, G., Dev, C. (2005), Service innovation and customer choices in the hospitality industry, Managing Service Quality, Vol. 15, No. 6, pp. 555-576.

von Hippel, E. (2005), Democratizing Innovation, The MIT Press, Cambridge Mass., London, England, available under Creative Commons license by Internet.

Watkins, M. (2013), What is Organizational Culture? And Why Should we Care? Harvard Business Review, May 15, 2013.

Wernerfelt, B. (1984), A resource-based view of the firm, Strategic Management Journal, Vol. 5, No. 2, pp. 171-180. Zakaria, N., Amelinckx, A., Wilemon, D. (2004), Working Together Apart? Building a Knowledge-Sharing Culture for Global Virtual Teams, Creativity and Innovation Management, Vol. 13, No. 1, pp. 15-29.

Zeng, S.X., Xie, X.M., Tam, C.M. (2010), Relationship between cooperation networks and innovation performance of SMEs, Technovation, No. 30, pp. 181-194.

Zheng, W. (2009), The knowledge-inducing culture: an integrative framework of cultural enablers of knowledge management, Journal of Information and Knowledge Management, Vol. 8, No. 3, pp. 213-227. 
